JURNAL

TATA KELOLA DAN AKUNTABILITAS KEUANGAN NEGARA

Volume 6, Number 2, Jul-Dec 2020, 195-211

e-ISSN 2549-452X

p-ISSN 2460-3937

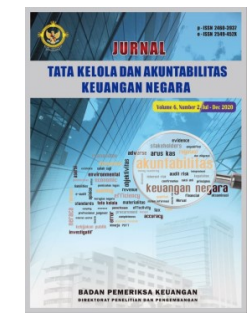

\title{
THE AUDIT BOARD OF THE REPUBLIC OF INDONESIA'S OPINION: BETWEEN REGIONAL FINANCIAL PERFORMANCE AND PUBLIC WELFARE (THE STUDY ON REGENCIES AND CITIES IN RIAU PROVINCE)
}

\author{
Golden Victor Vica Roy Saragih ${ }^{1}$, Arby Novrika Hasibuan ${ }^{2}$ \\ Badan Pemeriksa Keuangan Republik Indonesia, Indonesia ${ }^{1,2}$ \\ golden.saragih@bpk.go.id ${ }^{1}$ \\ arby.hasibuan@bpk.go.id ${ }^{2}$
}

\begin{abstract}
This study aims to determine and analyze the influence of local government financial performance on public welfare with the opinion of The Audit Board of the Republic of Indonesia (BPK) as mediation. This study was quantitative using panel data of 12 regencies and cities in Riau Province. The secondary data used was local government financial performance data, public welfare data, and the opinion from BPK Riau Representative from 2014 to 2018. The data analysis tool used for the hypothesis testing was path analysis with the SEM-PLS approach. The result shows that local government financial performance has been positively and significantly correlated to the public welfare in the regencies and cities in Riau Province, but not significant to the BPK's opinion. Besides, the BPK's opinion also does not correlate to public welfare. These findings indicate that the opinion of BPK has not been able to verify the correlation between the local government's financial performance and public welfare. Thus, it cannot be a benchmark in predicting the public welfare level.
\end{abstract}

\section{KEYWORDS:}

Public welfare; financial performance; BPK's opinion

DOI: $10.28986 /$ jtaken.v6i2.466 


\section{INTRODUCTION}

The central and local governments must submit accountability reports in the form of financial statements as a concrete effort to realize good governance and increase transparency and accountability in government financial management. The report form of accountability for local government financial management for the one-year budget is in the form of Local Government Financial Statement (Laporan Pemeriksaan Keuangan Daerah, LKPD), consisting of the Budget Realization Report, Statement of Financial Position, Statement of Cash Flow, and Notes to Financial Statement. Public sector accounting practices undertaken by government agencies have gained much attention over the previous days. There is a greater demand for transparency and public accountability by public sector institutions (Mardiasmo, 2009). Local government's financial statements need to be audited to improve its quality of transparency and accountability. Besides, the information in the financial reporting presented must meet the qualitative characteristics, so it can be used in decision making (Siregar, 2012).

The information in the financial statements must be presented reasonably based on the generally accepted accounting principles In order to fulfill the qualitative characteristics. Therefore, it is necessary to validate the financial statements that are intended to assess the fairness of financial statements based on the general accounting principles in Indonesia (Akbar \& Mar'aini, 2020). Independent auditors are required to assess the quality of financial statements presented by local governments. Independent auditors assessing the quality of LKPD in Indonesia's government system is The Audit Board of the Republic of Indonesia (Badan Pemeriksa Keuangan, BPK). BPK is a free and independent state agency in examining the state's financial management and responsibilities
(BPK RI, 2017). The result of the financial examination conducted by BPK is in the form of the audit opinion, audit finding, audit conclusions, as well as recommendations in the Semester Audit Summary (Ikhtisar Hasil Pemeriksaan Semester, IHPS) as stated in Article 2, Law Number 15 of 2006.

Local government financial statements audit aims to provide certainty whether the financial statements have been presented fairly per generally accepted accounting principles. The remediation efforts made by the audit board and the related parties after the disclosure of audit finding are the most important factor in determining the extent to which government audits can act as a tool that encourages transparency and accountability of the government (Wei, Qin, \& Tang, 2010). The obligation to the accountability of financial performance by the public requires local governments to provide clear information about their performance.

Performance measurements are usually done for several aspects namely, financial aspects, customer satisfaction, internal operations and markets, employee satisfaction, community and stakeholders' satisfaction, also time effectiveness (Bastian, 2006). Performance measurement is crucial to assessing organizational accountability and managers in delivering better public services. The public sector performance measurement system aims to help public managers assess the achievement of a strategy through financial and non-financial measuring instruments (Sumarjo, 2010). Accountability in the context of the public sector is a trustee (Government) obligation to give accountability, presenting, reporting and disclosing all activities that become its responsibility to the public who has the right to request such accountability (Kluvers, 2003; Kluvers \& Tippett, 2010). This statement implies that in the management of local government there is an agency relationship between the public as 
principal and local government as an agent.

Agency theory is a concept that explains the contractual relationship between a principal and an agent. The principal is the party that mandates the agent to carry out all activities on behalf of the principal in his capacity as a decision-maker. In Indonesia, the regional budget document is called the regional revenue and expenditure budget, for provinces, regencies, and cities. The budget preparation process involves two parties, namely the executive and the legislature, each through a team or budget committee. Agency theory sees that there are a lot of information asymmetries between agents who have direct access to information with the public. There is an information asymmetry that allows the occurrence of malpractice or corruption by the agent (Jensen \& Meckling, 1976).

Apart from agency theory, another theory that underlies this research is the stakeholder theory. The stakeholders are groups or individuals who can influence or be influenced by the process of achieving organizational goals. Stakeholder theory is a group of people, community or public, both as a whole and partially, who have a relationship and interest to the organization (Bryson, 2004). Success in public and private organizations is the extent to which the organization can guarantee the satisfaction of the main stakeholders (the community as the main stakeholder). The government as the holder of power in the wheels of government must emphasize aspects of the interests of the people as stakeholders (Putro, Furqan \& Brilliyanti, 2019).

Accountability assessment through audits of government financial statements in Indonesia is carried out annually by the BPK. The audit result is an opinion on the fairness of financial information presented in the financial statements. The type of opinions given by the auditor, including Unqualified Opin- ion (Wajar Tanpa Pengecualian, WTP), Modified Unqualified Opinion (Wajar Tanpa Pengecualian Dengan Paragraf Penjelasan, WTP-DPP), Qualified Opinion (Wajar Dengan Pengecualian, WDP), Adverse Opinion (Tidak Wajar, TW), and Disclaimer of Opinion (Tidak Memberikan Pendapat, TMP). WTP is the highest-ranking audit opinion where the auditor believes that the financial statements have fairly presented all material components/financial transactions. As for the other three opinions, each opinion reflects that there are still material weaknesses in the presentation of the government financial statements.

Apart from financial audits, BPK also conducts performance audits and special purpose audits (Pemeriksaan Dengan Tujuan Tertentu, PDTT). Performance audits aim to assess government performance which includes aspects of the economy, efficiency, and effectiveness of programs or activities. The results of the performance audit are focused on improving government policy. Meanwhile, PDTT includes compliance audits and investigative audits. In contrast to financial audits, performance audits and special purpose audits are not conducted annually but based on the BPK's risk assessment and strategic plan. BPK's auditors are required to comply with the State Financial Audit Standards (Standar Pemeriksan Keuangan Negara, SPKN) in conducting the audits. The SPKN itself contains the Audit Standard Statement (Pernyataan Standar Pemeriksaan, PSP) 200 regarding the audit implementation standards, which mandates that auditors must design and carry out appropriate audit procedures to obtain sufficient and appropriate audit evidence (Astuti \& Adrison, 2019).

BPK Representative Office in Riau Province had audited 13 LKPDs in 2016. From 13 LKPDs, 11 LKPDs of regencies and cities were awarded WTP opinions except for 
Rokan Hilir Regency and Dumai City (BPK, 2016). In 2017, 12 LKPDs of regencies and cities had gained WTP opinions, except for the LKPD Rokan Hilir regency which was still in WDP opinion (BPK, 2017). While in 2018 all LKPDs have obtained WTP opinions (BPK, 2018). Appreciation for achieving WTP's opinion to government agencies is reasonable with these difficulties. The obsession to obtain the WTP opinion is not merely a short-term purpose, but rather as a form of accountability and responsibility of the state's financial management correctly (Putry \& Badrudin, 2017). The phenomenon in the submission of accountability reports is that there are still many elements of public doubt regarding the relationship of audit opinion with the public welfare. This doubt is acceptable, considering that there are still local governments that accept the WTP opinion even though their welfare indicators are still low.

Similarly, some areas show the achievement of relatively good public welfare but obtained non-WTP opinion (Akbar \& Djazuli, 2015). This raises doubts about whether there is a close correlation between audit opinions and public welfare. In this case, there is a need for research related to the achievement of the results of the financial statement audit in the form of BPK's opinion obtained by the local government, whether it has a significant effect on the social welfare in Riau Province.

\section{Local Government Financial Perfor- mance}

Local government financial performance is the achievement of a work result in regional finance which includes the budget and realization of local own-source revenue and capital expenditures using financial indicators that are determined through a policy or statutory provisions from one budget period. The performance measurement design uses financial ratios from the elements of the regional head's accountability report in the form of calculating the regional expenditure budget. The ratio refers to a number that shows the relationship of an element with other elements in the financial statements. A ratio is compared with the ratio of similar companies so that with this comparison the situation and performance of the company can be evaluated (Halim, 2004).

Financial ratios, as a company performance analysis instrument, describe various relationships and financial indicators. Its purpose is to show changes in the financial condition or past operating performance and helps to illustrate the trend of such change patterns to show the risks and opportunities inherent in the company concerned. This shows that financial ratio analysis, although based on past data and conditions, is aimed at assessing risks and opportunities in the future (Halim, 2004). One of the performance measurement tools is the analysis of regional financial ratios, which is the core of performance measurement as well as the concept of managing government organizations to ensure public accountability by government agencies to the wider community. According to Halim (2004), the results of the financial ratio analysis can be used to assess the local government's financial independence in financing the implementation of regional autonomy, measure the efficiency and effectiveness in realizing local government revenue and measure the extent of government activities in spending it. Also, it measures the contribution of each source of revenue in the formation of local government revenue and observes the growth/ development of revenue and expenditure generated during a certain period.

Local government finance is an allocation of regional resources and media that is used to evaluate the local government's performance in financing regional development for public 
welfare. Financial ratio analysis (financial independence ratio, growth ratio, activity ratio) needs to be done in measuring the financial performance of local governments by comparing the performance achieved from several periods (Badrudin, 2015). The financial performance of local governments at this time has not been said to be maximal, because there are still areas that rely on central government finance. Local governments have not been able to explore and maintain regional resources and there are still a lot of allocating funds for routine expenditures. This condition has resulted in declining public welfare.

According to Suryaningsih, Utama, and Yasa (2015), the success of local governments in managing the regional finance implicates the increasing in economic growth per capita consumption and decreasing the Gini ratio number. This affects the condition of health, education, and social life so that the community will be more prosperous. The better the quality of governance, the better the financial accountability of the region will be. Public participation in paying local taxes and levies will illustrate the level of public welfare. A government with good financial performance is a capital for a country in serving the needs of its people. Budget allocation and realization have become more efficient and effective for human development because the administration of government is peopleoriented and committed to realizing it. The hypotheses composed based on these descriptions are:

H1: Local government financial performance has a significant influence on public welfare

Article 1 paragraph 37 of Minister of Home Affairs Regulation Number 21 of 2011 concerning the second amendment to Minister of Home Affairs Regulation Number 13 of 2006 states that financial performance analysis is an attempt to identify financial characteristics based on available financial statements. Meanwhile, performance is the output/result of activities/programs that will be or have been achieved in connection with the use of the budget with measurable quantity and quality. In this study, local government financial performance defined as an increasing in the achievement of a work result in the regional finance which includes the budget and the realization of Local Ownsource Revenue (Pendapatan Asli Daerah, PAD) using financial indicators that are determined through a policy or statutory provisions from one budget period (Halim, 2013). Halim and Damayanti (2007) mention several financial performance measurements in public sector organizations namely:

1. Local Government Financial Independence (Fiscal Autonomy)

Local government financial independence (fiscal autonomy) shows the ability of local governments to self-finance government activities, development, and services to people who have paid taxes and levies as a source of revenue needed by the region.

2. Local Own-source Revenue Effectiveness The ratio of effectiveness illustrates the ability of local governments to realize the planned PAD as compared to the target set, based on the real potentials of the region.

3. Activity (Compliance)

This activity ratio illustrates how local governments prioritize their optimal allocation of funds for routine expenditure and development expenditure.

4. Degree of Decentralization

The degree of decentralization shows the degree of PAD contribution to total regional revenue. The higher the PAD contribution, the higher the regional capacity in implementing decentralization will be.

5. Financial Dependency

Financial dependency is calculated by comparing the amount of transfer income with total regional income. 
On the other hand, the audit opinion is a professional statement as an auditor's conclusion on the fairness of financial information presented in the financial statements. This opinion can be used as a benchmark or indicator to assess the accountability of an entity. The published opinion will be able to raise stakeholders' trust in the reporting presented by the audited party. In other words, the better the performance of a local government then should be able to show the better the audit opinion. This is evidenced by a variety of researches on financial performance and audit opinions conducted by previous researchers.

One of them is from the research of Putry and Badrudin (2017) which examines the influence of local government financial performance on the audit opinion in the Special Region of Yogyakarta Province. The research results that there is a strong positive correlation and influence between the financial performance of the local government with the audit opinion. The financial performance is prescribed through the PAD divided by the total transfer income from the central government. The ability of the local government to increase success and achieve priorities for budget allocation in development spending will influence the increase in audit opinion. Likewise, Rozy and Wijayanti (2014) state that there is a strong positive correlation and influence between the financial performance of the local government with the audit opinion in Central Java Province. However, Marfiana and Kurniasih (2013) found different findings from the BPK examination results and the financial performance of regency and city governments. The results show that the audit opinion is not sufficient to explain its relation to the financial performance of a local government. Thus the hypothesis offered:

H2: Local government financial performance has a significant influence on BPK's opinion.

\section{Audit Opinion}

An opinion is a professional statement as the auditor's conclusion regarding the fairness of the information presented in the financial statement (BPK RI, 2017). Opinions must be based on audits carried out by audit standards and the auditor's findings. The results of the accountant's examination are contained in a report which states whether the financial statements have been fairly presented by generally accepted accounting principles. BPK's auditor conducts a financial audit based on four criteria i.e. compliance with the public accounting standards, adequacy of disclosure, compliance with legislation, and effectiveness of internal control systems.

The better the BPK audit opinion obtained, this shows the better the government management is in managing its resources to provide better public services (Masdiantini \& Erawati, 2016). Different findings are found by Akbar and Djazuli (2015) in their study on the financial audits and welfare of people in Badung regency, cities of Tabanan, and Denpasar with comparison techniques and scatter plots. The result proves empirically there is no strong correlation between the audit on financial statements or LKPD in particular with the public welfare. The audit on financial statements compares between accounting and finance practices in local government and the government accounting standard that has not fully considered economic welfare indicators. Therefore the third hypothesis is:

$\mathrm{H}_{3}$ : BPK's opinion has a significant influence on public welfare

\section{Public Welfare}

Public welfare can be seen from the measurement of the results of community development in achieving a better life, which includes the increasing ability and equal distri- 
bution of basic needs such as food, housing, health, and protection. Also, there are the increasing living levels, income levels, better education, and attention to culture and human values. Besides, there is an expansion of economies of scale and the availability of social options for individuals and countries (Todaro \& Smith, 2006). United Nations Development Programme (UNDP) measures people's welfare more comprehensively by using the Gross Regional Domestic Product (Produk Domestik Regional Bruto, PDRB) per capita, poverty level, and life expectancy which is constructed into the human development index (Kusuma \& Badrudin, 2016).

Local government performance can be measured by the level of welfare of the local community (Mangkunegara, 2015). The welfare uses a microeconomic analysis approach in the form of optimizing the use of economic resources or efficiency which is analyzed in the aggregate (Akbar \& Djazuli, 2015). The economic welfare indicators used include economic growth rate, PDRB per capita, poverty level, human development index, unemployment rate, and Gini Ratio.

Analysis of the performance of local governments in managing regional finances using financial ratio analysis of the regional expenditure budget means comparing the performance achieved in a certain period with the previous period and producing a trend. One of the assessments of local government financial performance can be seen from the BPK's audit opinion. The emergence of the opinion that performance measurements can improve the efficiency, effectiveness, savings, and productivity of the public sector organizations has caused great attention to welfare orientation (Halachmi, 2005). Ideally, the better financial management of the state, manifested with WTP opinion from BPK, will increase public welfare. This is due to the use of state finances is for public welfare. Welfare is the human ability to fulfill the needs of clothing, food, housing, education, and prosperity.

Welfare focus is the optimal allocation of resources using the microeconomic analysis approach of optimizing the use of economic resources or efficiency analyzed in aggregate. The welfare concept is very relevant to discuss the correlation between government performance in the financial management of the country with the opinion of BPK because the welfare indicators are the outputs and outcomes resulting from economic resources through the activities of government programs (Musahadah \& Amarullah, 2018). From this description, the fourth hypothesis developed is:

H4: Local government performance indirectly, through BPK's opinion, has a significant influence on public welfare

The existence of several differences and inconsistencies of research results led to this important research to do. Noticing some of the results of the previous studies, this study tries to incorporate several different variables with audit opinion variables positioned as mediation variables between local government performance and public welfare. The reason for the authors to choose the BPK's opinion variable is to determine the extent of the relationship between the achievement of the financial statement audit results in the form of BPK's opinion obtained by the regional government to regio-nal financial performance. Also, whether it has a significant effect on the public welfare in Riau Province.

Therefore, the contribution of this research is to show whether the implementation of good governance and an inclusive economic development model can be analyzed by the achievement of the opinion of the government audit that will describe the level of public welfare. Through the formulated hypothesis, the study aims to determine and 
analyze the effect of local government financial performance on the level of public welfare with audit opinion as a mediation. Furthermore, it is hoped that this study can explain how big the role of BPK's opinion is in influencing financial performance in improving public welfare and providing input to related parties (stakeholders).

\section{RESEARCH METHOD}

The object of this study was audit opinion, local government revenue, regional cash expenditures, the growth rate of PDRB based on constant prices, poverty level, and HDI in regencies and cities in the Riau provincial government. The variables are described from several theories and previous research. The conceptual framework can be illustrated in Figure 1.

This study was quantitative with data that supports the research and analysis using a data panel of 12 regencies and cities in the province of Riau from 2014 to 2018. The data source in this research is secondary data. The types of data used in this research are quantitative and qualitative data. Quantitative data is data in the form of numbers that can be measured in units of calculation while qualitative data is data in the form of words, sentences, schemes, and pictures or the form of information and is not in the form of numbers (Akbar, 2020). The quantitative data in this study were the regencies and cities' Go- vernment Budget Realization Report in Riau Province for the period 2014 to 2018. The qualitative data used is the BPK's opinion information contained in the BPK's IHPS for the 2014-2018 period as well as other information that supports this study. The operational variables and indicators used in this study are illustrated in Table 1.

The data analysis used was Structural Equation Modelling-Partial Least Square (SEMPLS). PLS is an analysis of a variant-based structural equation that can simultaneously test the model of measurement (outer model) and structural model (inner model) (Jogiyanto \& Abdillah, 2012). The measuring model was used for validity and reliability testing through the algorithm iteration process resulting in measurement model parameters, including the $\mathrm{R}^{2}$ value as predictive model precision. While the structural model is used to predict the causality correlation between latent variables through the bootstrapping process which results in a $\mathrm{T}$ statistic test parameter to predict the presence of causality correlation. Observation data amounted to 60, is data from 12 regencies and cities during the 5 year observation period. Therefore, this approach was chosen based on the small amount of observational data used in the study sample (less than 100).

SEM-PLS aims to test the predictive relationship between constructs by seeing whether there is a relationship or influence

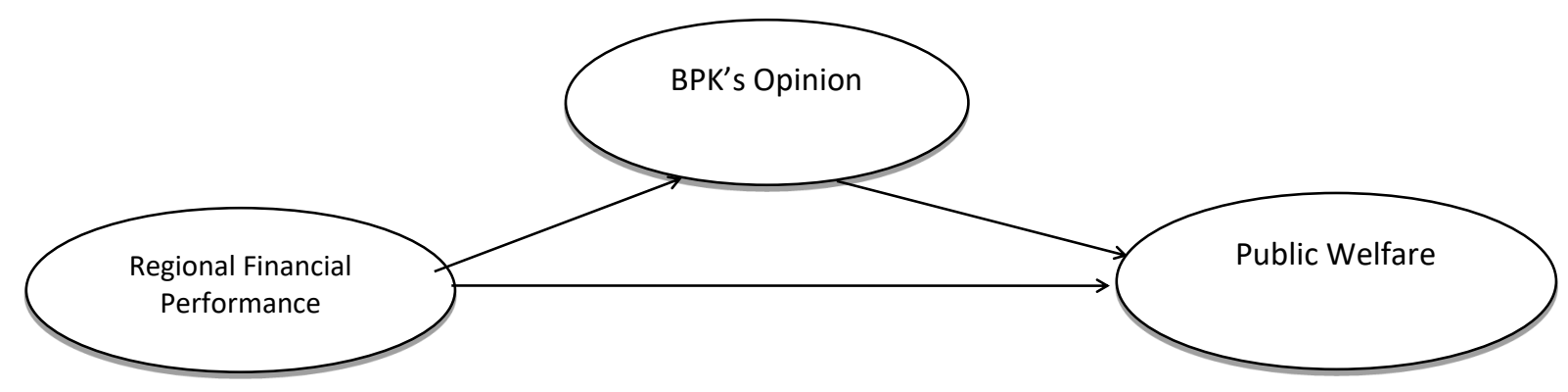

Figure 1. Conceptual Framework 
Table 1. Operational Variables

\begin{tabular}{|c|c|c|}
\hline Variable & Variable Definition & Indicator \\
\hline $\begin{array}{l}\text { Local Government Fi- } \\
\text { nancial Performance }(X)\end{array}$ & $\begin{array}{l}\text { The output/outcome of the activities/programs that } \\
\text { will or has been achieved following the use of bud- } \\
\text { gets with measurable quantity and quality. }\end{array}$ & $\begin{array}{l}\text { 1. Local Government Financial Independence } \\
\text { (Fiscal Autonomy) } \\
\text { 2. Local Own-source Revenue Effectiveness } \\
\text { 3. Acitivity (Compliance) } \\
\text { 4. Degree of Desentralization } \\
\text { 5. Financial Dependence }\end{array}$ \\
\hline BPK's opinion (Y) & $\begin{array}{l}\text { A statement provided by a registered auditor stating } \\
\text { that the audit has been conducted under the norm or } \\
\text { the accountant examination rules followed with the } \\
\text { opinion on the fairness of the financial statements } \\
\text { examined. }\end{array}$ & $\begin{array}{l}\text { 1. Disclaimer of Opinion (TMP) } \\
\text { 2. Adverse Opinion (TW) } \\
\text { 3. Qualified Opinion (WDP) } \\
\text { 4. Modified Qualified Opinion (WTP-DPP) } \\
\text { 5. Unqulified Opinion (WTP) }\end{array}$ \\
\hline Public Welfare (Z) & $\begin{array}{l}\text { Indicators of community development outcome in } \\
\text { achieving a better life which includes the increasing } \\
\text { ability and equality of distribution of basic needs. }\end{array}$ & $\begin{array}{l}\text { 1. PDRB per capita } \\
\text { 2. Poverty rate } \\
\text { 3. Human Development Index (HDI) }\end{array}$ \\
\hline
\end{tabular}

Source: Halim and Damayanti (2007), Todaro \& Smith (2006), Mulyadi (2014), Law of the Republic of Indonesia Number $15 / 2004$

between these constructs that can be tested without a strong theoretical basis, ignoring some assumptions (non-parametric) and predictive model accuracy parameters seen from the coefficient of determination (R- Square, $\mathrm{R}^{2}$ ). Ghozali (2014) divides two types of constructs, namely constructs with reflective indicators and constructs with formative indicators. This study uses a construct with a reflective indicator because the variable construct describes the indicator. The construct with the reflective indicator assumes that the covariance between the measurement models is explained by the variant which is the manifestation of the construct domain with the direction of the indicator from construct to indicator. Each indicator must be added with the error terms or measurement error.

In this study, data analysis using PLS starts from the evaluation of the measurement model (outer model), evaluation of the model structure (inner model), and hypothesis testing (path coefficient analysis). The outer model or measurement model defines how each indicator block relates to its latent variable. The outer model analysis is carried out to en- sure that the indicator used is suitable for measurement (valid and reliable). Outer model analysis can be seen from several indicators namely convergent validity, discriminant validity, and reliability test.

1. Convergent Validity

Ghozali (2014) states that convergent validity is related to the principle that the measures of a construct should be highly correlated. Convergent validity test of reflective indicators can be seen from the loading factor value for each construct indicator. In general, the rule of thumb for assessing convergent validity is confirmatory research, the loading factor value must be more than 0.7. For exploratory research, the loading factor value is between 0.6-0.7 and the Average Variance Extracted (AVE) value must be greater than 0.5. However, the loading factor value of $0.5^{-0.6}$ is still considered sufficient for research in the early stages of developing a measurement scale (Chin, 1998 in Ghozali, 2014).

2. Discriminant Validity 
Ghozali (2014) states that discriminant validity is related to the principle that different construct measures should not be highly correlated. The discriminant validity test with reflective indicators can be done by looking at the cross-loading value for each variable and must be $>0.70$, also comparing the square root of the AVE for each construct with the correlation value between constructs in the model. The square root of AVE for each construct is greater than the correlation between constructs in the model showing good discriminant validity (Fornell \& Larcker, 1981).

\section{Reliability Test}

Reliability tests are carried out to prove the accuracy, consistency, and accuracy of instruments in measuring constructs (Ghozali, 2014). Measuring the reliability of a construct with reflective indicators can be done with Cronbach's alpha or composite reliability. Ghozali (2014) suggests a reliability test using composite reliability. In general, the rule of thumb for assessing construct reliability is 1) for confirmatory research, it must be greater than 0.7 and 2) for exploratory research it is still acceptable for reliability values from 0.6 to 0.7 .

The inner model or structural model analysis is carried out to ensure that the structural model is built firmly and accurately. The model describes the relationship between latent variables based on the substantive theory. Designing a structural model is designing the relationship between latent variables in PLS based on the formulation of the problem or hypothesis. R square and the significance of the path coefficient through the Bootstrap procedure can be used to assess the structural model of the PLS technique (Henseler, et al., 2009 in Jogiyanto \& Abdillah, 2012).

1. The coefficient of determination $\left(\mathrm{R}^{2}\right)$
Ghozali (2014) states that in assessing structural models with PLS, it is first necessary to look at the $\mathrm{R}^{2}$ value of each endogenous latent variable as the predictive strength of the structural model. Changes in the value of $\mathrm{R}^{2}$ can explain the effect of certain exogenous latent variables on endogenous latent variables whether they have a substantive effect. A model can be assessed as strong or not known from the $\mathrm{R}^{2}$ value. $\mathrm{R}^{2}$ values of $0.75,0.50$, and 0.25 can be concluded that the model is strong, moderate, and weak. The results of PLS R ${ }^{2}$ represent the number of variants of the construct described by the model.

\section{Coefficient Path Analysis}

After the results of the evaluation of the structural model and measurement model are obtained, hypothesis testing is carried out by looking at the coefficient of influence and the t-statistic value. The hypothesis is accepted if the t-statistic is greater than the t-table (1.96) and the p-value is smaller than the significance value (0.05). The estimated value of the structural path coefficient in the model (estimate for path coefficients) is the path coefficient value that shows the magnitude of the influence of the variable (construct). This estimated value is evaluated using the t-statistical test obtained through the bootstrapping procedure (Ghozali, 2014). The application of the re-sampling method in bootstrapping allows the data to be distributed freely (distribution-free), does not require normal distribution assumptions, and does not require a large sample (a minimum sample of 30 is recommended). The test was carried out using the t-test statistic (t-test), with the criteria if the obtained p-value $\leq 0.05$ (alpha $=5 \%$ ), it was concluded significant, if the obtained p-value> 0.05, it was not significant. 
Data was taken from all regencies and cities in Riau Province, namely 10 regencies (Kampar, Siak, Meranti Islands, Bengkalis, Kuantan Singingi, Indragiri Hulu, Indragiri Hilir, Rokan Hulu, Rokan Hilir, Pelalawan) and 2 cities (Pekanbaru, Dumai) with periods 2014-2018. There are 9 indicators used so that 540 data were analyzed in the PLS study through three stages, namely evaluation of the measurement model (external model), evaluation of the structural model (inner model), and path analysis to test the hypothesis.

\section{Measurement Model Evaluation (Outer Model)}

The measurement Model (outer model) describes the correlation between the indicator and the variable. Evaluation of the measurement model includes the validity of the construct and reliability of the conduction. The validity of the construct is a form of testing that is intended to identify a contractual correlation with the indicator. Construct validity test consists of convergent validity using the loading factor on the outer loading and the validity of the discriminant using the average variance extracted (Ghozali, 2014). Convergent validity is shown in Table 2. According

Table 2. The Validity of Convergent Result (Loading Value)

\begin{tabular}{cccc}
\hline Indicator & $\begin{array}{c}\text { Public } \\
\text { Welfare }\end{array}$ & $\begin{array}{c}\text { Financial } \\
\text { Performance }\end{array}$ & $\begin{array}{c}\text { BPK's } \\
\text { opinion }\end{array}$ \\
\hline X1 & 0.989 & \\
\hline X2 & -0.320 & \\
\hline X3 & & -0.053 & \\
\hline X5 & 0.982 & 1.000 \\
\hline Y & & \\
\hline Z1 & & \\
\hline Z2 & 0.960 & \\
\hline Z3 & -0.743 & \\
\hline
\end{tabular}

to Table 2, there are some invalid indicators from the outer loading test because the value is below 0.50 (P-value $>5 \%$ ). The invalid indicators are $\mathrm{X}_{2}, \mathrm{X}_{3}$, and $\mathrm{X}_{5}$ in the financial performance variable, also $\mathrm{Z}_{1}$ and $\mathrm{Z}_{2}$ in the public welfare variable. Other invalid indicators were removed (not used for further analysis).

After the validity testing, further reliability testing was carried out to measure the internal consistency of the measuring instrument. Construct is considered reliable if it has composite reliability and Cronbach's Alpha value above 0.60 (Nunnally, 1978). Average AVE is also used for the evaluation of discriminant validity, and the criteria should be above 0.50 (Fornell \& Lacker, 1981). The result of the construction reliability test for this study is presented in Table 3 that shows composite reliability and Cronbach's Alpha has been qualified above 0.60. Likewise, the AVE value is above 0.50. Therefore, it can be con-

Table 3. The Construction Reliability Test Result

\begin{tabular}{clcc}
\hline Variable & $\begin{array}{c}\text { Cronbach } \\
\text { 's Alpha }\end{array}$ & $\begin{array}{c}\text { Composite } \\
\text { Reliability }\end{array}$ & AVE \\
\hline $\begin{array}{c}\text { Financial } \\
\text { Performance (X) }\end{array}$ & 0.689 & 0.793 & 0.665 \\
\hline BPK's opinion (Y) & 1.000 & 1.000 & 1.000 \\
\hline Public Welfare (Z) & 0.665 & 0.620 & 0.506 \\
\hline
\end{tabular}

cluded that the construct in this study is reliable. Overall, the result of the measurement model (outer model) is eligible for further analysis.

\section{Structural Model Evaluation (Inner Model)}

Structural Model Evaluation (inner model) is performed to determine the most common determinations in explaining the changes that occur to the other constructs. The structural Model in PLS is evaluated using $\mathrm{R}^{2}$ 
which is used to measure the variation rate of the variable change independently from the dependent variable. The higher the value of $\mathrm{R}^{2}$ means the better the prediction of the proposed research model. The $\mathrm{R}^{2}$ value from the SmartPLS output for public welfare is 0.644 while BPK's opinion is 0.001. That means the local government financial performance and BPK's opinion can explain the variances that occurred to the public welfare $64.4 \%$. The remaining $35.6 \%$ are explained by other factors that are not found in this research model. Whereas BPK's opinion variables are not yet explained from the local government financial performance variances due to the low $\mathrm{R}^{2}$ value of $0.1 \%$.

\section{Coefficient Path Analysis}

The analysis of data processing results in the full model of PLS was done by conducting a conformity test and statistical test. The result of the structural model is shown in Figure 2. that shows the mutual influence between the latent variables by looking at $\mathrm{t}$-statistic and $\mathrm{P}$ values. When the t-statistic is greater than 1.96 and the P-value is smaller than 0.05 then the latent variable gives a significant effect on the other latent variables. Conversely, when the t-statistic is smaller than
1.96 and the P-value is greater than 0.05, the latent variable does not give a significant effect to other latent variables (Ferdinand, 2012).

Impact analysis is aimed at seeing how strongly the influence of a variable with other variables is either direct or indirect. The Tvalue and the coefficient of structural models have summarized in Table 5 , the result of the hypothesis testing. Testing on the direct effect of local government financial performance on public welfare empirically proves that financial performance provides a positive and significant direct influence on the public welfare in the regencies and cities in Riau Province. Thus, it can be concluded that better local government financial performance will increase the level of public welfare. Conversely, if the financial performance of the local government is bad, it will be predictable that the level of public welfare in the area is also low. The result of this research is the same as the research of Putry and Badrudin (2017) as well as Suryaningsih, Utama, and Yasa (2016) who find that there is a positive correlation between financial performance and public welfare. The increasing local government financial performance will be able to manage the region's potentials

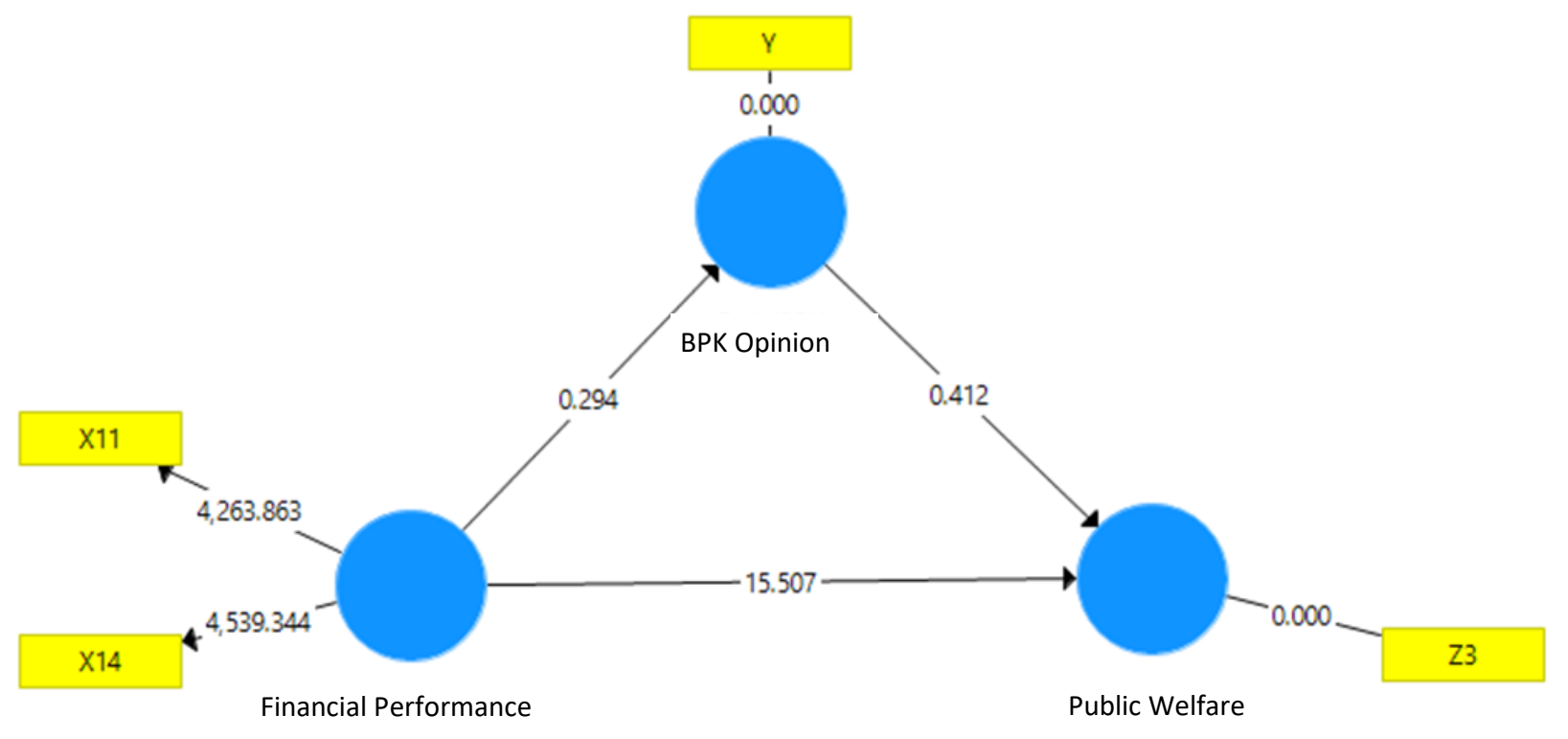

Figure 2. The Structural Model Test Result 
Table 5. Hypothesis Test Results

\begin{tabular}{ccccccc}
\hline Hypothesis & $\begin{array}{c}\text { Coefficient } \\
\text { (Original Sample) }\end{array}$ & Mean & SD & T-Statistics & P -Values & Result \\
\hline H1 & 0.800 & 0.789 & 0.052 & 15.330 & 0.000 & Accepted \\
\hline H2 & 0.036 & 0.037 & 0.118 & 0.308 & 0.758 & Declined \\
\hline H3 & 0.035 & 0.043 & 0.076 & 0.460 & 0.646 & Declined \\
\hline H4 & 0.001 & 0.003 & 0.014 & 0.090 & 0.928 & Declined \\
\hline
\end{tabular}

such as natural resources, human resources, and financial resources optimally. This will also lead to increasing public welfare. Thus, the first hypothesis (H1) is approved.

The second hypothesis is the influence of local government financial performance on BPK's opinion. Based on the result of analysis and testing, it can be concluded that the local government financial performance has a positive influence, but not significant to the opinion of $\mathrm{BPK}$, or $\mathrm{H} 2$ is declined. This means that the better financial performance has not been a guarantee that the local government will get good BPK's opinion. This is due to BPK's opinion is a professional statement of the auditor regarding the fairness of financial information presented in financial statements based on compliance with government accounting standards, adequate disclosures, compliance with laws and regulations, and the effectiveness of the internal control system. The result supports the research by Marfiana and Kurniasih (2013) stating that the audit opinion is not enough to explain the correlation between financial performance of the local government. This shows that the opinion of a good local government audit is not necessarily showing the local government's financial performance either. On the other hand, Rozy and Wijayanti (2014) also Putry and Badrudin (2017) find that there is a positive influence between the local government financial statement and the audit opinion.

Testing of the third hypothesis shows that the BPK's opinion has no effect on public wel- fare, meaning that $\mathrm{H}_{3}$ is declined. The result of this research is in line with the research of Musahadah and Amarullah (2018) who find that the audit opinion has no positive and significant effect on the public welfare. BPK's opinion cannot be used as a benchmark to predict the level of public welfare. According to Law Number 11 of 2009, social welfare is the condition of fulfilling the material, spiritual, and social needs of citizens to be able to live properly and develop themselves, so they can carry out their social functions. Statistics Indonesia (2000) explains that indicators of household welfare that can be mea-sured include the level of household income, the composition of household expenditures by comparing expenditure on food and non-food items; family education level, family health level, and condition of housing and facilities owned by the household. BPK's opinion is related to the fairness of the financial information presented in the financial statements and not related to the five indicators above. This shows the fact that BPK needs to include the welfare audit in the process of local government finance audit, from planning activities and implementation to reporting, which is concrete to support the achievement of public welfare.

Furthermore, the $\mathrm{H} 4$ test in this study shows that the financial performance of the local government indirectly through the BPK opinion has no significant effect on the public welfare. Thus, $\mathrm{H}_{4}$ is declined. The BPK's opinion has not been able to provide a mediating effect on the influence of the financial perfor- 
mance of local governments in regencies and cities throughout Riau on the public welfare.

The financial management of the central and local governments is philosophically used in a transparent, responsible, and comprehensive manner for the public welfare. On the internal side of the local government, there is a strengthening of the internal control system, as well as tight supervision from the inspectorate. The results are in line with research conducted by Akbar and Djazuli (2015) which proves that indirectly local government financial performance has an influence on public welfare through BPK's opinion. The examination of the public welfare remains untouched by the current audit model. Some quantitative pieces of evidence show that WTP opinion is not yet able to describe the prosperity and welfare of the local community. It can be concluded that the audit opinion of BPK obtained by a local government cannot indicate better public welfare.

\section{CONCLUSION}

Based on the analysis and discussion that has been presented, it can be concluded that the financial performance of the local government demonstrated from the local government's ability in financial independence, PAD effectiveness, activity/compliance, degree of decentralization, and financial dependence, has a significant positive effect on public welfare in the regencies and cities in Riau Province. The more productive local government performance illustrates the better the level of public welfare. With this, local government financial performance will provide ease of implementation of the activities and government programs in the efforts to improve the welfare of the public.

BPK's opinion of LKPD in Riau Province does not have a significant effect on public welfare. The same thing prevails on the financial performance which has a small effect on BPK's opinion. The audit findings do not investigate if the government's activities have been in line with the target, but only examine the non-conformity of the activity with the constitutional regulations. On the other side, BPK's opinion cannot give the mediation effect on the effect of the financial performance of the regency and city governments within Riau Province to provide public welfare. The absence of a significant effect of BPK's opinion on Riau public welfare shows that BPK's audit opinion obtained by the local government still cannot indicate the improvement of public welfare itself.

The suggestions given are for the BPK to carry out a comprehensive audit by applying a Long Form Audit Report (LFAR) which includes both financial and performance audits at the same time. So that, in addition to providing opinions on financial statements, BPK also provides an assessment of the success or failure of the government in designing and implementing development programs that have an impact on improving public welfare. For the performance audit program carried out in conjunction with financial audits, BPK will focus on programs related to improving people's welfare, for example: health insurance, education insurance, poverty alleviation and employment provision and, in a wider scope, examining achievement indicators of welfare nationally.

Meanwhile, the local governments should be more accurate and comprehensive in preparing and presenting financial and performance reports in the framework of accountability for their budgets. The local government must also explain the work achievements achieved in using the budget in a reliable, complete promptly to determine the success in the implementation of the Regional Government Financial Reporting System. The authors certainly realize that there are still 
some weaknesses and needs for improvement/perfection. Therefore, for further research, the authors suggest it is necessary to consider the use of questionnaire techniques, use of other variables, and expand the scope of research.

\section{REFERENCES}

Akbar, B., \& Djazuli, A. (2015). Audit keuangan dan kesejahteraan rakyat studi pada Kabupaten Badung, Tabanan dan Kota Denpasar Tahun 2013. Jurnal Tata Kelola dan Akuntabilitas Keuangan Negara, 1(1), 1-19. DOI: 10.28986/jtaken.v1i1.9

Akbar, Y. R. (2020). Analisis kuantitatif, pengolahan data statistik menggunakan SPSS \& pengumpulan data survei Google Form/Survey Monkey. Purwokerto: CV Pena Persada.

Akbar, Y. R., \& Mar'aini. (2020). Implementasi sistem informasi pengelolaan keuangan daerah dengan pendekatan model penerimaan teknologi terhadap kualitas Laporan Keuangan Pemerintah Daerah Provinsi Riau. Bilancia: Jurnal Ilmiah Akuntansi, 4 (1), 92-101.

Astuti, Y. D., \& Adrison, V. (2019). The audit board of Indonesia's opinion and bribery in local governments in Indonesia. Jurnal Tata Kelola dan Akuntabilitas Keuangan Negara, 5(2), 125138. DOI: 10.28986/jtaken.v5i2.379

Badrudin, R. (2015). Evaluation of the specific allocation fund for Indonesian society welfare. International Journal of Applied Business and Economics 13 (7), 5607-5624.

Bastian, I. (2006). Akuntansi sektor publik : Suatu pengantar. Jakarta: Penerbit Erlangga.

BPK RI. (2016). Ikhtisar Hasil Pemeriksaan Semester (IHPS) I Tahun 2016 (Summary of Semester Audit Results I Year 2016). Retrieved from htps:// www.bpk.go.id/ihps.

BPK RI. (2017). BPK Regulation Number 1 Year 2017 concerning State Financial Audit Standards (Peraturan Badan Pemeriksa Keuangan Republik Indo- nesia Nomor 1 Tahun 2017 tentang Standar Pemeriksaan Keuangan Negara). Retrieved from http://www. spkn. bpk. go. id.

BPK RI. (2017). Ikhtisar Hasil Pemeriksaan Semester (IHPS) I Tahun 2017 (Summary of Semester Audit Results I Year 2017). Retrieved from htps:// www.bpk.go.id/ihps.

BPK RI. (2018). Ikhtisar Hasil Pemeriksaan Semester (IHPS) I Tahun 2018 (Summary of Semester Audit Results I Year 2018). Retrieved from htps:// www.bpk.go.id/ihps.

Bryson, J. M. (2004). What to do when stakeholders matter: Stakeholder identification and analysis techniques. Public management review, 6(1), 21-53. DOI: $10.1080 / 1471903041000167572$ 2

Ferdinand, A. (2012). Structural equation modeling dalam penelitian manajemen aplikasi model-model rumit dalam penelitian untuk Tesis magister dan desertasi doktor. Semarang: BP Universitas Diponegoro.

Fornell, C. R., \& Lacker, D. F. (1981). Evaluating structural equation models with unobservable variables and measurement error. Journal of Marketing Research, 18(1)39-50. DOI: 10.2307/ 3151312

Ghozali, I. (2014). Partial least square. Semarang: Universitas Diponegoro.

Government Regulation of the Republic of Indonesia Number 58 of 2005 concerning Regional Financial Management as amended by Government Regulation Number 12 of 2019 (Peraturan Pemerintah Republik Indonesia Nomor 58 Tahun 2005 tentang Pengelolaan Keuangan Daerah yang diubah dengan Peraturan Pemerintah Nomor 12 Tahun 2019). Retrieved from https://peraturan.bpk.go.id/Home/ Details/103888/pp-no-12-tahun2019.

Hair, J., Black, W., Babin, B., \& Anderson. (2008). Multivariate data analysis (5th Ed.). New Jersey: Prentice Hall International Inc.

Halachmi, A. (2005). Performance measurement is only one way of managing performance. International Journal of 
Productivity and Performance Management, 5(4), 502-516. DOI: $10.1108 / 17410400510622197$

Halim, A. (2004). Manajemen keuangan daerah. Yogyakarta: UPP AMP YKPN.

Halim, A., \& Damayanti, T. (2007). Pengelolaan keuangan daerah. Yogyakarta: UPP STIM YKPN.

Halim, A. (2013). Akuntansi keuangan daerah: akuntansi sektor publik. Jakarta: Salemba Empat.

Jensen, M. C., \& Meckling, W. H. (1976). Theory of the firm: Managerial behavior, agency costs, and ownership structure. Journal of financial economics, 3(4), 305-360. DOI: 10.1016/0304-405X(76)90026-X

Jogiyanto., \& Abdillah, W. (2012). Konsep dan aplikasi PLS (Partial Least Square) untuk penelitian empiris. Yogyakarta: BPFE-Yogyakarta.

Kluvers, R. (2003). Accountability for performance in local government. Australian Journal of Public Administration, 62(1), 57-69. DOI: 10.1111/1467-8500.00314

Kluvers, R., \& Tippett, J. (2010). Mechanisms of accountability in local government: an exploratory study. International Journal of Business and Management, 5(7), 46. DOI: $10.5539 /$ ijbm.v5n7p46

Kusuma, M. W., \& Badrudin, R. (2016). Fiscal decentralization effect on economic growth in Bali. Economic Journal of Emerging Markets, 8(1), 136-147. DOI: 10.20885/ejem.vol8. iss2.art6

Law of the Republic of Indonesia Number 15 of 2004 concerning State Financial Management and Accountability $\mathrm{Au}-$ dit (Undang- Undang-Undang Republik Indonesia Nomor 15 Tahun 2004. Pemeriksaan Pengelolaan dan Tanggung Jawab Keuangan Negara). Retrieved from https:// peraturan.bpk.go.id/Home/ Details/40509/uu-no-15-tahun2004.

Law of the Republic of Indonesia Number 15 of 2006 concerning The Audit Board of Republic of Indonesia. (UndangUndang Nomor 15 Tahun 2006 ten- tang Badan Pemeriksa Keuangan.). Retrieved from https:// peraturan.bpk.go.id/Home/ Details/40184/uu-no-15-tahun2006.

Mangkunegara, I. (2015). Pengaruh karakteristik keuangan dan hasil pemeriksaan pada kesejahteraan masyarakat di Provinsi Sumatera Utara. Jurnal Tata Kelola dan Akuntabilitas Keuangan Negara, 1(2), 141-155. DOI: 10.28986/jtaken.v1i2.24

Mardiasmo. (2009). Akuntansi sektor publik. Yogyakarta: Penerbit ANDI.

Marfiana, N., \& Kurniasih, L. (2013). Pengaruh karakteristik pemerintah daerah dan hasil pemeriksaan audit BPK terhadap kinerja keuangan pemerintah daerah kabupaten/kota. Journal \& Proceeding FEB UNSOED, 3(1).

Masdiantini, P. R., \& Erawati, N. M. (2016). Pengaruh ukuran pemerintah daerah, kemakmuran, intergovermental revenue, temuan dan opini audit BPK pada kinerja keuangan. Jurnal Akuntansi Universitas Udayana, 14 (2), 1150-1182.

Minister of Home Affairs Regulation Number 21 of 2011 concerning second amendment from Minister of Home Affairs Regulation Number 13 of 2006 (Peraturan Menteri Dalam Negeri No. 21 Tahun 2011 tentang perubahan kedua dari Peraturan Menteri Dalam Negeri Nomor 13 Tahun 2006). Retrieved from https:// www.kemendagri.go.id/arsip/ detail/6564/pedoman-pengelolaankeuangan-daerah.

Mulyadi, P. (2014). Auditing dan pemeriksaan akuntansi. (Edisi Pertama). Jakarta: Salemba Empat.

Musahadah., \& Amarullah, R. (2018). Unqualified opinion and public welfare : A paradox. Bormeo Administrator, 14 (2), 135-150. DOI: 10.24258/ jba.v14i2.335

Nunnally, J. (1978). Psychometric theory. (2nd Ed.). New York: McGraw-Hill.

Putro, H. P. H., Furqan, A., \& Brilliyanti, A. (2019). The position of stakeholders involved in the collaboration of the tourism destination governance in 
Pangandaran, West Java-Indonesia. Journal of Management Info, 6(1), 22 -26. DOI: $10.31580 /$ jmi.v6i1.488

Putry, N. A., \& Badrudin, R. (2017). Pengaruh kinerja keuangan daerah terhadap opini audit dan kesejahteraan masyarakat Daerah Istimewa Yogyakarta. Jurnal Riset Manajemen dan Bisnis, 12(1), 25-34.

Rozy, M. A., \& Wijayanti, P. (2014). The influence of the audit opinion, the original area of revenue and the equalization fund to regional financial performance. Jurnal Akuntansi Indonesia, 3(2), 81-100. DOI: 10.30659/ jai.3.2.81-100

Siregar, S. R. (2012). Faktor-faktor yang mempengaruhi pertimbangan opini auditor atas laporan keuangan pemerintah Daerah Istemawa Yogyakarta. Accounting Analysis Journal, 1 (2), 1-8. DOI: 10.15294/aaj.v1i2.554

Statistics Indonesia. (2000). Statistical year book of Indonesia. Retrieved from https://www.bps.go.id/ publication/2001/05/15/ e243f32294d3de6o68a7d3e3/ statistik-indonesia-200o.html.

Sumarjo, H. (2010). Pengaruh karakteristik pemerintah daerah terhadap kinerja keuangan pemerintah daerah. Retrieved from https:// eprints.uns.ac.id/406o/

Suryaningsih, N. N., Utama, M. S., \& Yasa, I. M. (2015). Dampak kinerja keuangan daerah terhadap kesejahteraan masyarakat kabupaten/kota di Provinsi Bali. Jurnal Ekonomi dan Bisnis, 4(08), 537-554.

Todaro, M. P., \& Smith, S. C. (2006). Economic development. (9th Ed.). New York: Pearson Addison Wesley.

Wei, D. H., Qin, Z. Y, \& Tang, S. Q. (2010). Research on the relation between the efficiency of government audit and the security of financial fund: Some evidence from the data of national yearbook. Auditing Research, 3, 9-14.

\section{ACKNOWLEDGEMENT}

The authors would like to thank Mr. T. Ipoeng Andjar Wasita as the head of BPK Riau Representative, and Mr. Tulus Budhisatria Rikit as The Head of Sub-Div Public Relation and Administration of BPK Riau Province Representative. 